\title{
Implementation of Guidance and Counseling in Kaliwungu Elementary School
}

\author{
Ngaenu Rofiqoh, Lutfia Islahati, Nita Eka Rahmawati, Moh Salimi \\ Universitas Sebelas Maret \\ ngaenurofiqoh16@gmail.com
}

Article History

accepted 24/09/2019

approved 01/10/2019

published 01/12/2019

\begin{abstract}
Guidance and counseling is an inseparable part of the education system. Likewise at Kaliwungu Elementary School which has implemented the Guidance and Counseling program. The Guidance and Counseling Program is implemented to direct and overcome problems experienced by students, both in academic and non-academic fields. These problems include lazy and slow in learning, undisciplined, fight, and so forth. The purpose of this study was to find out how the implementation of guidance and counseling programs at Kaliwungu elementary school. This method of research is a qualitative descriptive study with interview and observation technique. The results of this study indicate that the implementation of the guidance and counseling program at Kaliwungu elementary school is carried out by the class teacher. The form of guidance given is individual guidance and group guidance. Individual counseling is an ecletive counseling by the teacher advising and directing students according to the problem. Group guidance in the form of remedial teaching and home room program.
\end{abstract}

Keywords: Guidance, Counseling, Elementary School

\begin{abstract}
Abstrak
Bimbingan dan konseling merupakan suatu bagian yang tidak dapat dipisahkan dari sistem pendidikan. Begitu juga dengan SD Negeri Kaliwungu yang sudah melaksanakan program Bimbingan dan Konseling. Program Bimbingan dan Konseling tersebut dilaksanakan untuk mengarahkan dan mengatasi permasalahan yang dialami oleh siswa, baik dalam bidang akademik maupun non akademik. Masalah tersebut diantaranya malas dan lambat dalam belajar, tidak disiplin, suka berkelahi, dan lain sebagainya. Tujuan dari penelitian ini untuk mengetahui bagaimana pelaksanaan program bimbingan dan konseling di SD Negeri Kaliwungu. Metode penelitian yang digunakan adalah penelitian deskriptif kualitatif dengan teknik pengumpulan data wawancara dan observasi. Hasil penelitian ini menunjukkan bahwa pelaksanaan program bimbingan dan konseling di SD Negeri Kaliwungu dilaksanakan oleh guru kelas. Bentuk bimbingan yang diberikan yaitu bimbingan individu dan bimbingan kelompok. Bimbingan individu berupa konseling eklektif yaitu, dilakukan dengan cara guru menasehati dan mengarahkan siswa sesuai dengan masalahnya. Sedangkan untuk bimbingan kelompok metode yang digunakan yaitu metode pengajaran remedial dan home room.
\end{abstract}

Kata kunci: Bimbingan, Konseling, Sekolah Dasar

Social, Humanities, and Education Studies (SHEs): Conference Series https://jurnal.uns.ac.id/shes 


\section{PENDAHULUAN}

Menurut Undang-undang No. 20 Tahun 2003 Pendidikan adalah usaha sadar dan terencana untuk mewujudkan suasana belajar dan proses pembelajaran agar siswa secara aktif mengembangkan potensi dirinya untuk memiliki kekuatan spiritual keagamaan, pengendalian diri, kepribadian, kecerdasan, akhlak mulia, serta keterampilan yang diperlukan dirinya, masyarakat, bangsa dan negara. Sedangkan menurut Suyadi (2013) pendidikan adalah upaya sadar dan terencana dalam proses pembimbingan dan pembelajaran bagi individu agar tumbuh berkembang menjadi manusia yang mandiri, bertanggung jawab, kreatif, berilmu, dan berakhlak (berkarakter). Sehingga Pendidikan dapat diartikan sebagai usaha sadar dan terencana dalam proses bimbingan dan pembelajaran untuk mengembangkan potensi spiritual keagamaan, pegendalian diri, kepribadian, kecerdasan, akhlak mulia dan keterampilan agar menjadi manusia yang berkarakter.

Sedangkan tujuan dari Pendidikan berdasarkan Undang-Undang No. 20 Tahun 2003 tentang Sistem Pendidikan Nasional telah dicantumkan tujuan dari pendidikan nasional. Pendidikan nasional bertujuan untuk mengembangkan potensi siswa menjadi manusia yang beriman dan bertakwa kepada Tuhan Yang Maha Esa, berilmu, cakap, kreatif, mandiri, dan menjadikannya sebagai warga negara yang demokratis serta bertanggung jawab. Berdasarkan tujuan pendidikan nasional tersebut sudah sangat jelas bahwa siswa dituntut untuk menjadi manusia yang seutuhnya, mulai dari bertakwa kepada Tuhan Yang Maha Esa hingga dapat menjadi warga negara yang demokratis serta bertanggung jawab.

Menurut Nugroho (2016) untuk mewujudkan tujuan pendidikan nasional, maka perlu mengintegrasikan seluruh komponen yang ada dalam pendidikan, salah satunya adalah komponen bimbingan dan konseling. Menurut Asmani (2010) bimbingan adalah proses pemberin bantuan yang dilakukan oleh seorang ahli kepada individu dengan menggunakan berbagai prosedur, cara, dan bahan agar individu tersebut mampu mandiri dalam memecahkan masalah-masalah yang dihadapinya. Sedangkan, konseling merupakan proses pemberian bantuan yang didasarkan pada prosedur wawancara konseling oleh seorang ahli kepada yang bermuara pada teratasinya masalah yang dihadapi klien.

Seperti yang telah diketahui bahwa setiap siswa memiliki karakteristik pribadi atau perilaku yang berbeda dengan siswa lainnya. Hal ini sesuai dengan pendapat dari Kusmanto (2016) bahwa siswa asuh memiliki karakteristik yang unik, yang berbeda antara siswa satu dengan siswa lain. Dengan adanya perbedaan ini maka masalah yang dimiliki setiap siswa pun berbeda juga. Ada yang hanya memiiki masalah kesulitan belajar atau hanya masalah dalam berperilaku saja. Bahkan ada yang memiliki kedua masalah tersebut. Selain itu ada yang memiliki masalah lain yang berasal dari keluarga, lingkungan maupun dari diri sendiri. Dalam hal ini, guru dituntut untuk mengetahui asal usul dan kepribadian setiap siswa agar guru dapat memperoleh cara untuk menghadapi siswa yang bermasalah. Maka dari itu perlu adanya pengumpulan data terhadap siswa. Dengan data yang lengkap, guru akan dapat memberikan layanan bimbingan dan konseling kepada siswa secara tepat atau terarah.

Menurut Tohirin (2008), metode bimbingan individu dibagi menjadi tiga, yaitu: Konseling Direktif dalam prosesnya yang aktif atau paling berperan adalah konselor. Dalam praktiknya konselor berusaha mengarahkan konseli sesuai dengan masalahnya. Selain itu konselor juga memberikan saran, anjuran dan nasihat kepada konseli.

Konseling Non-Direktif dalam praktiknya konselor hanya menampung pembicaraan. Konseli bebas berbicara sedangkan konselor menampung dan mengarahkan. Metode ini tentu sulit diterapkan untuk siswa yang berkepribadian tertutup, karena siswa yang berkepribadian tertutup biasanya pendiam dan sulit untk 
diajak berbicara. Cara ini belum bisa diterapkan secara efektif untuk murid Sekolah Dasar dan dalam keadaan tertentu siswa SMP. Metode ini bisa diterapkan secara efektif untuk siswa tingkatan SMA dan mahasiswa di Perguruan Tinggi.

Konseling Eklektif Siswa di sekolah memiliki tipe-tipe kepribadian yang tidak sama. Oleh sebab itu, tidak mungkin diterapkan metode konseling direktif saja atau nondirektif saja. Agar konseling berhasil secara efektif dan efisien, tentu harus melihat siswa yang dibantu atau dibimbing dan melihat masalah yang dihadapi siswa dan melihat situasi konseling. Apabila terhadap siswa tertentu tidak bisa diterapkan metode direktif maka mungkin bisa diterapkan metode nondirektif, atau penggabungan metode tersebut yang disebut dengan metode eklektif. Penerapan metode dalam konseling ini adalah dalam keadaan tertentu konselor menasehati dan mengarahkan konseli (siswa) sesuai dengan masalahnya, dan dalam keadaan yang lain konselor memberikan kebebasan kepada konseli untuk berbicara sedangkan konselor mengarahkan saja.

Program bimbingan dan konseling sangat diperlukan dalam pelaksanaan instruktural atau aktivitas yang berhubungan dengan pengelolaan atau manajemen sekolah dan aktivitas bimbingan serta pelayanan lain bagi kesejahteraan siswa, karena dalam prakteknya tidak sedikit diantara siswa dalam mengikuti proses belajar mengajar mengalami kesulitan dalam menangkap dan memahami isi pelajaran yang disampaikan oleh guru. Siswa yang mengalami kesulitan belajar dipastikan memerlukan layanan spesifik yakni berupa perlakuan yang mampu membangkitkan semangat belajarnya, menumbuhkan motivasi yang rendah kadarnya sehingga muncul dorongan untuk belajar mengejar ketertinggalan dari temannya. (Widada, 2015).

Layanan bimbingan dan konseling di Sekolah Dasar merupakan layanan yang paling tepat diberikan kepada siswa agar siswa tersebut dapat berkembang secara optimal sesuai dengan bakat dan minatnya, mampu mengendalikan dan mengarahkan diri dan lingkungannya sehingga siswa mampu memecahkan masalah dalam kehidupannya sendiri. Hal ini sesuai dengan pendapat Pratiwi (2017) bahwa dalam layanan bimbingan konseling perorangan guru membantu siswa dalam menghadapi masalah pribadi siswa. Layanan bimbingan dan konseling memfasilitasi Layanan bimbingan dan konseling berfungsi untuk memfasilitasi siswa dengan cara memberikan informasi, menyampaikan pengarahan, memberikan motivasi dan memudahkan siswa mengenali diri sendiri melalui tes serta menunjukkan resiko atas pilihan yang telah diberikan.

Menurut Prasasti dan Efendi (2018) bahwa bimbingan konseling untuk anak usia dini sangat penting karena pada usia tersebut adalah golden age otak manusia dimana otak manusia sangat baik sekali dalam mengingat segala hal baik hal buruk maupun hal baik. Oleh karena itu, guru bk harus bersinergi bersama orang tua agar usia golden age anak tidak terlewati dengan sia-sia. Namun rata-rata di sekolah dasar tidak memiliki guru BK tetapi pelayanan BK diberikan oleh guru kelas seperti yang terjadi di SD Negeri Kaliwungu.

Tujuan penelitian ini yaitu untuk mengetahui pelaksanaan bimbingan dan konseling serta metode yang diterapkan di SD Negeri Kaliwungu.

\section{METODE}

Dalam penelitian ini, metode penelitian yang digunakan ialah deskriptif kualitatif. Jenis penelitian deskriptif adalah penelitian yang bermaksud untuk membuat pencandraan (deskriptif) mengenai situasi-situasi atau kejadian-kejadian. (Suryabrata, 2014). Sedangkan Kualitatif adalah metode penelitian yang berlandaskan pada filsafat pospsitivisme, digunakan untuk meneliti pada kondisi obyek yang alamiah, dimana peneliti adalah sebagai instrument kunci, dan hasil penelitian kualitatif lebih menekankan makna daripada generalisasi. (Sugiyono, 2011) dimana penulis lebih berfokus pada mendeskripsikan suatu kejadian atau fenomena yang diperoleh di lapangan sesuai dengan topik permasalahan, yaitu pelaksanaan program bimbingan 
dan konseling di SD Negeri Kaliwungu, Kecamatan Klirong, Kabupaten Kebumen. Teknik pengumpulan data yang digunakan adalah wawancara dan observasi. Subjek penelitian adalah kepala sekolah dan enam orang guru kelas (kelas 1 sampai kelas 6). Sumber data pada penelitian ini terdiri dari data primer dan data sekunder. Sumber data primer diperoleh dari hasil wawancara kepada kepala sekolah dan guru kelas. Sedangkan untuk data sekunder dapat diperoleh dari referensi maupun literartur yang berkaitan.

\section{HASIL DAN PEMBAHASAN \\ 1. Pelaksanaan Bimbingan konseling di SD Negeri Kaliwungu}

Berdasarkan hasil observasi di SD Negeri Kaliwungu telah melaksanakan program bimbingan konseling. Program BK dilaksanakan oleh seluruh Guru kelas 1 sampai kelas 6 , dikarenanakan belum adanya tenaga profesional yang menangani Bimbingan dan Konseling. Apabila terdapat siswa yang memiliki permasalahan yang sulit untuk ditangani sendiri oleh guru kelas maka, guru kelas akan melakukan musyawarah dengan kepala sekolah dan guru-guru lain serta komite sekolah. Pelaksanaan BK di SD Negeri Kaliwungu seperti halnya dilakukan dalam penelitian Pelaksanaan Layanan Bimbingan Belajar Pada Siswa Kelas IV SD Negeri 1 Sukorini bahwa peran, fungsi serta tanggung jawab guru kelas tidak hanya sebagai pengajar tetapi juga sebagai seorang pembimbing. (Nugroho, 2016).

Program BK yang dilaksanakan di SD Negeri Kaliwungu berbentuk tertulis. Dalam artian semua hasil penanganan kasus bimbingan dan konseling dilaporkan dalam bentuk tertulis sebagai bagian dari arsip sekolah. Setiap guru kelas membuat buku khusus yang berisi tentang permasalahan siswa atau pengembangan bakat dan karir siswa. Kemudian dari semua buku catatan BK yang dimiliki guru kelas akan di tulis ulang dalam buku BK sekolah. Buku BK sekolah ini berisi masalah yang sudah dipilah mana yang penting dan perlu untuk dicatat. Namun Masih ada guru kelas yang belum membuat buku BK atau melakukan pencatatan kasus.

\section{Bentuk Pelaksanaan Bimbingan dan Konseling}

a. Tertulis

Masalah yang ditulis merupakan hal-hal yang bersifat besar atau perlu penanganan yang lebih. Permasalahan yang dilakukan siswa ditulis dalam buku Bimbingan Konseling Sekolah. Pada dasarnya terdapat buku bimbingan konseling yang dipegang oleh guru kelas masing-masing namun, guru kelas SDN Kaliwungu ini belum memasukkan permasalahan siswa di buku tersebut dan belum merekap semua data siswa yang melakukan bimbingan bakat atau sebagainya.

Selain buku bimbingan konseling yang berisi catatan permasalahan serta bimbingan, SD Negeri Kaliwungu menerapkan bimbingan secara tertulis untuk diberikan kepada wali siswa. Buku ini dinamakan "Buku Sambung". Buku sambung ini berisi tentang perkembangan anak serta nasihat atau arahan untuk wali siswa yang diharapkan dapat membimbing siswa saat berada di rumah atau selama di luar pengawasan guru. Selain itu, Buku Sambung digunakan untuk penilaian sikap siswa di selama sekolah. Saat terdapat masalah siswa yang perlu ditangani oleh wali siswa dan kegiatan yang diadakan di sekolah dalam waktu dekat maka, buku sambung akan dibagikan.

b. Tidak tertulis/Verbal

Bimbingan dalam bentuk verbal merupakan masalah siswa yang tingkatnya masih wajar/ringan. Bentuk bimbingan konseling verbal ini dilakukan seperti menasehati secara spontanitas terhadap siswa yang melakukan kesalahan atau masalah antara teman lainnya. Terkadang juga mengundang orang tua atau wali siswa agar melakukan bimbingan terhadap orang tuanya supaya dapat membimbing anaknya selama di rumah. 
Hal ini sama halnya dengan penelitian dari Pranoto dalam Skripsi Pelaksanaan Pelayanan Bimbingan dan Konseling oleh Guru Kelas di Sekolah Dasar Negeri Kecamatan Pecalungan Kabupaten Batang bahwa, di SD tersebut kegiatan pelaksanaan bimbingan dan konseling dibuat secara tertulis oleh guru kelas. Di samping itu SD Negeri Kaliwungu menerapkan pelaksanaan bimbingan koseling secara tidak tertulis/ verbal.

\section{Metode Pelaksanaan BK di SD Negeri Kaliwungu}

\section{a. Metode Bimbingan Individu}

Berdasarkan hasil wawancara dan observasi, di SD Negeri Kaliwungu terdapat beberapa masalah individu. Masalah yang sering muncul antara lain siswa enggan untuk mengerjakan PR, siswa sering tidak masuk, siswa kesulitan membaca dan menulis, serta siswa yang usil terhadap temannya. Untuk mengatasi masalah tersebut, para guru menggunakan metode yang sesuai dengan masalah yang dihadapi. Menurut Tohirin (2008) metode bimbingan individu dibagi menjadi yaitu direktif, non direktif, dan eklektif.

Berdasarkan ketiga metode bimbingan dan konseling individu di atas, guru di SD Negeri Kaliwungu lebih banyak menerapkan metode bimbingan dan konseling eklektif. Metode ini dianggap metode yang paling efektif karena merupakan gabungan dari metode direktif dan non direktif. Seperti halnya jika ada siswa yang tidak mengerjakan PR, guru akan memanggil siswa tersebut secara pribadi ke kantor untuk menanyakan alasan mengapa siswa tersebut tidak mengerjakan PR. Siswa diberi kebebasan untuk menjelaskan alasannya. Setelah itu guru menasihati dan mengarahkan agar siswa tidak mengulangi perbuatan tersebut.

b. Metode Bimbingan Kelompok

Menurut Tohirin (2008), macam-macam metode bimbingan dan konseling kelompok yaitu program home room, karyawisata, diskusi kelompok, kegiatan kelompok, organisasi siswa, sosiodrama, psikodrama, dan pengajaran remedial. Dari beberapa metode tersebut SD Negeri Kaliwungu tidak menerapkan semuanya melainkan beberapa saja yang dianggap sesuai dan mampu untuk mengatasi masalah kelompok yang muncul. Masalah kelompok yang sering muncul diantaranya siswa yang nilainya di bawah kriteria ketuntasan minimal, keadaan kelas yang kurang kondusif karena siswa ramai, dan perkelahian antar siswa.

Untuk mengatasi masalah siswa yang nilainya kurang dari KKM guru menggunakan metode remedial. Menurut Tohirin (2008) pengajaran remedial (remedial teaching) merupakan suatu bentuk pembelajaran yang diberikan kepada seorang atau beberapa orang siswa untuk membantu kesulitan belajar yang dihadapinya. Pada prinsipnya pelajaran remedial termasuk ke dalam bimbingan akademik (academic guidance) atau bimbingan belajar yang bersifat khusus. Metode remedial yang digunakan oleh guru di SD N Kaliwungu dilakukan dalam bentuk pengulangan materi pelajaran yang dilaksanakan di luar jam pelajaran. Dengan diterapkannya metode ini guru berharap siswa dapat meningkatkan pemahamannya sehingga terdapat peningkatan hasil belajar siswa.

Untuk mengatasi masalah keadaan kelas yang kurang kondusif guru menggunakan metode home room. Menurut Tohirin (2008), metode home room dilakukan di sekolah di luar jam pelajaran dengan menciptakan suatu kondisi sekolah atau kelas seperti di rumah sehingga tercipta suatu kondisi yang bebas dan menyenangkan. Di SD Negeri Kaliwungu penerapan metode ini dilaksanakan dengan cara mengarahkan siswa agar memperhatikan dan menghargai guru yang sedang berbicara. Selain itu, guru mengajak siswa untuk ice breaking atau bernyanyi agar siswa tidak bosan. 


\section{SIMPULAN}

Dari pembahasan di atas dapat disimpulkan bahwa:

1. Pelaksanaan program bimbingan dan konseling di SD Negeri Kaliwungu dilakukan oleh guru kelas. Bentuk bimbingan dan konseling yang dilakukan yaitu tertulis dan tidak tertulis.

2. Metode bimbingan dan konseling yang dilakukan guru SD Negeri Kaliwungu meliputi metode bimbingan individu dan kelompok. Metode bimbingan individu yang digunakan yaitu metode eklektif. Sedangkan metode kelompok yang digunakan yaitu metode pengajaran remedial dan metode home room.

\section{DAFTAR PUSTAKA}

Asmani, Jamal, M. (2010). Panduan Efektif Bimbingan dan Konseling di Sekolah. Jogjakarta: Diva Press.

Kholilah, N dan Khusumadewi, A. (2018). Implementasi Layanan Bimbingan dan Konseling di Sekolah Dasar Islam Terpadu At-Taqwa Surabaya. Universitas Negeri Surabaya. Diakses dari http://jurnalmahasiswa.unesa.ac.id pada 12 September 2019.

Kusmanto, A. S. (2016). Penggunaan Media Dalam Pelayanan Bimbingan dan Konseling. In Teaching, linguistics, culture, and education conference (Vol. 1). Badan Penerbit UMK. Diakses dari http://eprints.umk.ac.id pada 12 September 2019

Nugroho, D.S. (2016). Pelaksanaan Layanan Bimbingan Belajar pada Siswa Kelas IV SD Negeri 1 Sukorini. Jurnal Pendidikan Guru Sekolah Dasarr Edisi 32 Tahun Ke-5. Diakses dari http://journal.student.uny.ac.id pada 19 September 2019.

Prasasti, S \& Efendi, M. (2018). Program Bimbingan Konseling untuk Anak Usia Dini. Jurnal IImiah Konseling, BK FKIP UTP, VoL18 (1) Januari 2018. ISSN: 20861907. Diakses dari http://ejournal.utp.ac.id pada 28 September 2019.

Pratiwi, R. L. dan Wulandari M.D. (2017). Implementasi Layanan Bimbingan Konseling Berbasis Pendidikan Ramah Anak di SD Muhammadiyah 16 Surakata. PGSD Fakultas Keguruan dan IImu Pendidikan Universitas Muhammadiyah Surakarta. Diakses dari http://eprints.ums.ac.id pada 28 September 2019.

Sugiyono. (2015). Metode Penelitian Pendidikan (Pendekatan Kuantitatif, Kualitatif, dan R\&D) Cetakan ke 21. Bandung:Penerbit Alfabeta.

Suryabrata, Sumadi. (2014). Metodologi Penelitian. Jakarta: PT. Grafindo Persada.

Suyadi. (2013). Strategi Pembelajaran Pendidikan Karakter. Bandung: PT Remaja Rosdakarya

Tohirin. (2008). Bimbingan dan Konseling di Sekolah dan Madrasah (Berbasis Integrasi). Jakarta: PT Rajagrafindo Persada.

Widada. (2015). Program Bimbingan dan Konseling di Sekolah Dasar. Jurnal Pemikiran dan Pengembangan SD, Jilid 1, Nomor 1, April 2013, hlm. 65-75. Universitas Muhammadiyah Malang. Diakses dari http://ejournal.umm.ac.id pada 12 September 2019. 